\title{
PERSPEKTIF EKONOMI SYARIAH TENTANG PERANAN BANK SAMPAH TERHADAP KESEJAHTERAAN MASYARAKAT TEMPATAN
}

\author{
Boy Syamsul Bakhri* \\ *Fakultas Agama Islam (FAI) Universitas Islam Riau (UIR) Pekanbaru \\ Jl. Kaharuddin Nasution No. 113 Perhentian marpoyang Pekanbaru 28284 \\ e-mail : bsb_fai@fis.uir.ac.id
}

\begin{abstract}
Abstrak : Tujuan penelitian adalah untuk mengetahui peranan bank sampah terhadap kesejahteraan masyarakat tempatan dan bagaimana perspektif ekonomi syariah terhadap fenomena tersebut. Rumusan masalah dari penelitian ini adalah bagaimana peranan bank sampah terhadap kesejahteraan masyarakat tempatan dan bagaimana perspektif ekonomi syariah terhadap fenomena tersebut. Dalam menganalisis data kuantitatif digunakan analisis regresi linear sederhana dimana proses perhitungannya menggunakan SPSS for Windows versi 23,0. Sampel penelitian ini sebanyak 42 orang masyarakat tempatan yang menjadi nasabah dan pekerja dibank sampah yang ada di sekitar tempat tinggal mereka. Dari hasil penelitian ini diketahui peranan peranan bank sampah terhadap kesejahteraan masyarakat tempatan memiliki hubungan yang sangat erat, ini diketahui dari nilai koefisien korelasi sebesar 90,1\%. Sedangkan hasil uji parsial menunjukkan terdapat pengaruh yang signifikan antara peranan bank sampah terhadap kesejahteraan masyarakat tempatan, ini diketahui dari nilai thitung (13.164) lebih besar dari ttabel $(1,684)$ ini berarti secara parsial dapat diketahui bahwa variabel X (peranan bank sampah) berpengaruh terhadap variabel Y (kesejahteraan masyarakat tempatan). Dari perspektif ekonomi syariah, masyarakat tempatan telah memiliki kesejahteraan moral, kesejahteraan spiritual, dan kesejahteraan sosial. Sedangkan kesejahteraan material belum terpenuhi.
\end{abstract}

Kata kunci : Bank Sampah, Kesejahteraan, Ekonomi Syariah 


\section{PENDAHULUAN}

Bertambahnya penduduk dan perubahan pola konsumsi masyarakat menimbulkan bertambahnya volume, jenis, dan karakteristik sampah yang semakin beragam. Sampah telah menjadi permasalahan nasional sehingga pengelolaannya perlu dilakukan secara komprehensif dan terpadu dari hulu ke hilir, pengelolaan sampah diperlukan kepastian hukum, kejelasan tanggung jawab dan kewenangan pemerintah pusat, pemerintah daerah, serta peran serta masyarakat sehingga pengelolaan sampah dapat berjalan secara profesional, efektif dan efisien.

Kekeliruan dalam pengelolaan sampah akan berdampak pada pencemaran lingkungan. Pemerintah melalui UU Nomor 18 Tahun 2008 tentang Pengelolaan Sampah berusaha secara serius untuk mengurai, mengantisipasi dan mengurangi persoalan sampah tersebut. Selama ini masyarakat pada umumnya melakukan pengelolaan sampah melalui proses pengumpulan, pengangkutan dan pembuangan ke tempat pembuangan akhir sampah/TPAS. Padahal, setiap masyarakat memiliki volume sampah yang besar dan apabila diangkut menjadi satu akan menciptakan timbunan sampah yang besar dan berpotensi melepas gas metan ( $\mathrm{CH} 4)$. Hal tersebut berdampak pada peningkatan emisi gas rumah kaca dan pemanasan global. Maka lewat UU tersebut harus memperhatikan asas tanggungjawab, keberlanjutan, asas manfaat, keadilan, kesadaran, kebersamaan, keamanan dan asas nilai ekonomi, yang pengelolaannya dengan melibatkan peran serta masyarakat.

Sesuai dengan Pasal 3 UU Nomor

18 Tahun 2008 tentang Pengelolaan Sampah, disebutkan bahwa :"Pengelolaan sampah diselenggarakan berdasarkan asas tanggung jawab, asas berkelanjutan, asas manfaat, asas keadilan, asas kesadaran, asas kebersamaan, asas keselamatan, asas keamanan, dan asas nilai ekonomi". Aturan diatas secara tegas mengatur bahwa pengelolaan sampah harus didasarkan pada kesadaran bagi pemerintah untuk mengelola sampah dengan baik dan juga peran serta masyarakat sebagai bentuk nyata dari penerapan kebijakan pemerintah mengenai pengelolaan sampah yang baik dan benar sehingga dibutuhkan peran aktif masyarakat agar meningkatkan kesehatan bagi masyarakat dan kualitas lingkungan serta menjadikan sampah sebagai sumber daya.

Bank sampah adalah suatu tempat yang digunakan untuk mengumpulkan sampah yang sudah dipilah-pilah. Hasil dari pengumpulan sampah yang sudah dipilah akan disetorkan ke tempat pembuatan kerajinan dari sampah atau ke tempat pengepul sampah. Bank sampah dikelola menggunakan sistem seperti perbankan yang dilakukan oleh petugas sukarela. Penyetor adalah warga yang tinggal di sekitar lokasi bank serta mendapat buku tabungan seperti menabung di bank.

Kehadiran bank sampah sebagai bentuk partisipasi warga tersebut sangat penting sekali untuk memutus mata rantai panjang sampah rumah tangga ke tempat pembuangan akhir. Meskipun yang berkembang selama ini adalah bank sampah konvensional yang mekanisme bank sampah sendiri sebetulnya tidak jauh berbeda dengan bank-bank pada umumnya, hanya saja yang menjadi komoditas di bank sampah ini adalah sampah itu sendiri dan bukan uang. Dalam bank sampah terdapat mekanisme bagi hasil di mana keuntungan dari sampah yang dijual oleh bank sampah. Persentase bagi hasilnya pun bervariasi, ada yang dengan sistem tabungan, nasabah menabung dengan sampah dan dikonversi dengan nilai dan nominal tertentu sesuai harga pasar sampah yang ditabung, ada yang beli putus sebagaimana di tukang rongsokan. Dalam kasus seperti ini, bank sampah tentu saja mendapatkan persentase keuntungan yang lebih besar.

Pekanbaru merupakan salah satu dari sepuluh kota terbesar di Indonesia, dengan luas wilayah $632,27 \mathrm{~km} 2$ memiliki jumlah 
penduduk sekitar 1,3 juta penduduk. Dengan jumlah tersebut, tak heran jika pola produksi dan konsumsi di Pekanbaru ini juga tinggi. Fakta ini pula yang menyebabkan produksi sampah di Pekanbaru terus mengalami kenaikan setiap tahunnya. Dinas Kebersihan dan Pertamanan Kota Pekanbaru, menyatakan Pekanbaru mampu menghasilkan sampah 500 ton/hari. Secara rata- rata, 2,6 kilogram sampah diproduksi tiap penduduknya setiap hari. Sebagai salah satu langkah mengurangi masalah sampah yang ada diperkotaan, Kementerian Lingkungan Hidup melakukan pengembangan bank sampah. Hal ini dilakukan agar masyarakat dapat dengan bijak mengelola sampah yang ada di lingkungannya, sehingga penumpukan sampah yang ada di tempat pembuangan akhir tidak bertumpuk terlalu banyak. Hal ini didukung oleh Peraturan Daerah Kota Pekanbaru No. 8 Tahun 2014 tentang Pengelolaan Sampah di Kota Pekanbaru yang telah disetujui bersama Dewan Perwakilan Rakyat Daerah Kota Pekanbaru dan Walikota Pekanbaru pada tanggal 12 Desember 2014.

Bank sampah adalah salah satu bentuk ekonomi kreatif yang dilakukan oleh masyarakat. Allah SWT dalam AlQuran berulangkali mendorong manusia agar selalu menggunakan akalnya untuk berpikir kreatif. Dalam ajaran agama Islam, bekerja merupakan ibadah, dimana hakikat hukum ibadah adalah wajib. Sehingga dapat ditarik kesimpulan bahwa bekerja adalah kewajiban bagi umat muslim. Bagi seorang muslim, makna bekerja berarti niat yang kuat mewujudkan hasil kerja yang optimal, bukan hanya memberikan nilai ratarata.

Bank sampah merupakan salah satu solusi alternatif pengurangan jumlah sampah yang ada di Pekanbaru. Dalam melaksanakan operasionalnya, bank sampah ini membutuhkan tenaga kerja yakni karyawan yang bertugas mengumpulkan, memilah dan memproduksi sampah menjadi kerajinan yang memiliki nilai ekonomi. Karyawan yang dipekerjakan pada umumnya adalah para ibu rumah tangga yang berada di sekitar bank sampah. Para ibu rumah tangga ini sebelumnya tidak memiliki pekerjaan. Karyawan bank sampah terutama adalah ibu-ibu rumah tangga kini tidak lagi bersifat masyarakat konsumtif, tetapi telah menjadi masyarakat yang produktif dikarenakan telah memiliki sejumlah pendapatan dari tempat ia bekerja.

Dalam penelitian ini peneliti memilih Bank Sampah Dalang Collection sebagai tempat penelitian dikarenakan bank sampah ini merupakan bank sampah pusat dari semua bank sampah di Pekanbaru dan telah memiliki banyak bank sampah binaan di Pekanbaru. Karyawan Bank Sampah Dalang Collection sebelumnya belum memiliki pekerjaan tetap, setelah berdirinya Bank Sampah Dalang Collection karyawan dapat bekerja tetap sehingga memperoleh sejumlah penghasilan. Penghasilan yang mereka terima dapat membantu untuk memenuhi kebutuhan sehari-hari mereka. Jika kebutuhan sehari-hari mulai terpenuhi maka kesejahteraan karyawan pun diharapkan dapat meningkat. Dengan melihat fenomena di atas maka penulis ingin melihat apakah Bank Sampah Dalang Collection berpengaruh terhadap kesejahteraan masyarakat tempatan yang dilihat dari perspektif ekonomi syariah.

Setelah dilihat dari uraian latar belakang masalah tersebut di atas, maka dapat dikemukakan rumusan masalah dalam penelitian ini adalah bagaimana peranan bank sampah terhadap kesejahteraan masyarakat tempatan dan bagaimana perspektif ekonomi syariah melihat fenomena tersebut? Adapun tujuan dalam penelitian ini adalah untuk mengetahui peranan bank sampah terhadap kesejahteraan masyarakat tempatan dan bagaimana perspektif ekonomi syariah melihat fenomena tersebut. 


\section{TINJAUAN PUSTAKA \\ Peranan}

Dalam Kamus Besar Bahasa Indonesia, peranan berasal dari kata peran. Peran memiliki makna yaitu seperangkat tingkat diharapkan yang dimiliki oleh yang berkedudukan di masyarakat. Sedangkan peranan adalah bagian dari tugas utama yang harus dilaksanakan Soekanto (2015: 211), peranan merupakan aspek dinamis dari kedudukan yaitu seseorang yang melaksanakan hak-hak dan kewajibannya. Suatu peranan mencakup paling sedikit tiga hal berikut ini:

a. Peranan meliputi norma-norma yang dihubungkan dengan posisi atau tempat seseorang dalam masyarakat,

b. Peranan merupakan suatu konsep perihal apa yang dapat dilakukan oleh individu dalam masyarakat sebagai organisasi,

c. Peranan juga dapat diartikan sebagai perilaku individu yang penting bagi struktur sosial.

$$
\text { Suyomukti (2016: }
$$

mengatakan pembahasan perihal aneka peranan yang melekat pada individu dalam masyarakat penting karena hal-hal sebagai berikut:

a. Peranan-peranan tertentu harus dilaksanakan apabila struktur masyarakat hendak dipertahankan kelangsungannya,

b. Peranan-peranan dilekatkan pada individu-individu yang oleh masyarakat dianggap mampu untuk melaksanakannya. Mereka harus terlatih dan mempunyai hasrat untuk melaksanakannya,

c. Dalam masyarakat, kadang-kadang dijumpai individu yang tak mampu melaksanakan peranannya sebagaimana diharapkan masyarakat karena mungkin pelaksanaannnya memerlukan pengorbanan kepentingankepentingan pribadinya yang terlalu banyak,

d. Apabila semua orang sanggup dan mampu melaksanakan perannya, belum tentu masyarakat akan dapat memberikan peluang-peluang yang seimbang. Bahkan sering terlihat betapa masyarakat terpaksa membatasi peluang tersebut.

\section{Bank Sampah}

Menurut Peraturan Menteri Negara Lingkungan Hidup Republik Indonesia Nomor 13 Tahun 2012 tentang Pedoman Pelaksanaan Reduce, Reuse, dan Recycle melalui Bank Sampah, bank sampah adalah tempat pemilahan dan pengumpulan sampah yang dapat didaur ulang dan/atau di daur ulang yang memiliki nilai ekonomi. Bank sampah adalah suatu tempat yang digunakan untuk mengumpulkan sampah yang sudah dipilah-pilah. Hasil dari pengumpulan sampah yang sudah dipilah akan disetorkan ke tempat pembuatan kerajinan dari sampah atau ke tempat pengepul sampah. Bank sampah dikelola berdasarkan sistem seperti perbankan yang dilakukan oleh petugas sukarelawan.

Penyetor adalah warga yang tinggal di sekitar lokasi bank serta mendapat buku tabungan seperti menabung di bank. (Munawir, 2015: 32). Pada dasarnya bank sampah merupakan konsep pengumpulan sampah kering dan dipilah serta memiliki manajemen layaknya perbankan, tetapi yang ditabung bukan uang melainkan sampah. Warga yang menabung (menyerahkan sampah) juga disebut nasabah dan memiliki buku tabungan. Sampah yang ditabung akan ditimbang dan dihargai dengan sejumlah uang. Tujuan bank sampah adalah untuk membantu menangani pengolahan sampah di Indonesia, untuk menyadarkan masyarakat akan lingkungan yang sehat, rapi dan bersih, mengubah sampah menjadi sesuatu yang lebih berguna dalam masyarakat untuk kerajinan dan lainnya. Jadi dengan kata lain bank sampah sebagai upaya pemberdayaan masyarakat dalam pengelolaan atau pengolahan sampah dan sekaligus dalam penanganan lingkungan. 
Bank sampah adalah strategi untuk membangun kepedulian masyarakat agar dapat berteman dengan sampah untuk mendapatkan manfaat ekonomi langsung dari sampah. Jadi, bank sampah tidak dapat berdiri sendiri melainkan harus diintegrasikan dengan gerakan 3R (Reduce, Reuse, dan Recycle) sehingga manfaat langsung yang dirasakan tidak hanya ekonomi, namun pembangunan lingkungan yang bersih, hijau dan sehat.

Bank sampah juga dapat dijadikan solusi untuk mencapai pemukiman yang bersih dan nyaman bagi warganya. Dengan pola ini maka warga selain menjadi disiplin dalam mengelola sampah juga mendapatkan tambahan pemasukan dari sampahsampah yang mereka kumpulkan. Tampaknya pemikiran seperti itu pula yang ditangkap oleh Kementerian Lingkungan Hidup. Secara tidak langsung, bank sampah berperan dalam mengurangi dampak perubahan iklim. Seperti yang diketahui ternyata sampah juga menjadi salah satu faktor peningkatan jumlah emisi gas rumah kaca di atmosfer, selain kegiatan manusia lainnya yang berhubungan dengan energi, kehutanan, pertanian dan peternakan.

\section{Pengertian dan Kesejahteraan dalam Islam}

\section{Kesejahteraan}

adalah

pemenuhan kebutuhan atau keperluan yang bersifat ekonomi, jasmaniah dan rohaniah, baik di dalam maupun di luar hubungan kerja yang secara langsung atau tidak langsung dapat mempertinggi produktivitas kerja dalam lingkungan kerja yang aman dan sehat. Kesejahteraan merupakan program yang berkelanjutan yang disediakan atau dibantu oleh perusahaan atau organisasi. (Wirawan, 2015: 411).

Terdapat dua jenis kesejahteraan ekonomi, yaitu kesejahteraan ekonomi konvensional dan kesejahteraan ekonomi syariah. a. Kesejahteraan Ekonomi Konvensional

Kesejahteraan konvensional hanya menekankan pada kesejahteraan material berupa pemenuhan kebutuhan sandang, pangan, papan dan kesehatan dengan mengabaikan kesejahteraan spiritual dan moral. Dimana kesejahteraan konvensional menggunakan dua pendekatan dalam menentukan kesejahteraan ekonomi yaitu pendekatan Neo-Klasik dan pendekatan ekonomi kesejahteraan yang baru (modern). Pendekatan Neo-Klasik berasumsi bahwa nilai guna merupakan kardinal dan konsumsi tambahan itu menyediakan peningkatan yang semakin kecil dalam nilai guna.

b. Kesejahteraan Ekonomi Syariah

Kesejahteraan ekonomi syariah bertujuan mencapai kesejahteraan manusia secara menyeluruh, yaitu kesejahteraan material, kesejahteraan spiritual dan kesejahteraan moral. Konsep ekonomi kesejahteraan bukan saja manifestasi nilai ekonomi, tetapi juga nilai moral dan spiritual, nilai sosial dan politik Islam. Dalam pandangan syariah terdapat tiga sudut pandang dalam memahami kesejahteraan ekonomi yakni: Pertama, dilihat dari pengertiannya, sejahtera sebagaimana dikemukakan dalam Kamus Besar Bahasa Indonesia adalah aman, sentosa, damai, makmur, dan selamat (terlepas) dari segala macam gangguan, kesukaran dan sebagainya. Pengertian ini sejalan dengan pengertian "Islam" yang berarti selamat, sentosa, aman dan damai. Dari pengertian ini dapat dipahami bahwa masalah kesejahteraan sosial sejalan dengan misi Islam itu sendiri. Kedua, dilihat dari segi kandungannya, terlihat bahwa seluruh aspek ajaran Islam ternyata selalu terkait dengan masalah kesejahteraan sosial. Hubungan dengan Allah misalnya, harus dibarengi dengan hubungan sesama manusia. Demikian pula anjuran beriman selalu diiringi dengan menganjurkan amalan shaleh, yang di dalamnya termasuk mewujudkan kesejahteraan sosial. Ketiga, upaya 
mewujudkan kesejahteraan sosial merupakan misi kekhalifahan yang dilakukan sejak Nabi Adam AS.

Menurut Imam Al-Ghazali kegiatan ekonomi sudah menjadi bagian dari kewajiban sosial masyarakat yang telah ditetapkan oleh Allah SWT, jika hal itu tidak dipenuhi, maka kehidupan dunia akan rusak dan kehidupan umat manusia akan binasa. Selain itu, Al-Ghazali juga merumuskan tiga alasan mengapa seseorang harus melakukan aktivitas ekonomi, yaitu: pertama, untuk memenuhi kebutuhan hidup masing-masing. Kedua, untuk menciptakan kesejahteraan bagi dirinya dan keluarganya dan ketiga, untuk membantu orang lain yang sedang membutuhkan.

Menurut Pusat Pengkajian dan Pengembangan Ekonomi Islam (2008: 4), kesejahteraan menurut Islam mencakup dua pengertian, yaitu:

a. Kesejahteraan holistik dan seimbang, yaitu kecukupan materi yang didukung oleh terpenuhinya kebutuhan spiritual serta mencakup individu dan sosial. Sosok manusia terdiri atas unsuk fisik dan jiwa, karenanya kebahagiaan haruslah menyeluruh dan seimbang diantara keduanya. Demikian pula manusia memiliki dimensi individual sekaligus sosial. Manusia akan merasa bahagia jika terdapat keseimbangan diantara dirinya dengan lingkungan sosialnya.

b. Kesejahteraan di dunia dan akhirat (falah), sebab manusia tidak hanya hidup di alam dunia saja, tetapi juga di alam setelah kematian/kemusnahan dunia (akhirat). Kecukupan materi di dunia ditunjukkan dalam rangka untuk memperoleh kecukupan di akhirat. Jika kondisi ideal ini tidak tercapai maka kesejahteraan di akhirat tentu lebih diutamakan, sebab ini merupakan sesuatu yang abadi dan lebih bernilai (valuable) dibanding kehidupan dunia. Kesejahteraan dalam ekonomi Islam adalah kesejahteraan secara menyeluruh, yaitu kesejahteraan secara material maupun secara spiritual. Konsep kesejahteraan dalam ekonomi Islam tidak hanya diukur berdasarkan nilai ekonomi saja, tetapi juga mencakup nilai moral, spiritual dan juga nilai sosial. Sehingga kesejahteraan berdasarkan Islam mempunyai konsep yang lebih mendalam.

\section{Indikator Kesejahteraan Menurut Pandangan Islam}

Menurut Pusat Pengkajian dan Pengembangan Ekonomi Islam (2008 : 1-13), "Indikator kesejahteraan Islami adalah terpenuhinya kebutuhan fisik dan rezeki yang halal, hidup sehat secara jasmani dan rohani, keberkahan rezeki yang diterima, keluarga yang sakinah, mawaddah wa rahmah, rasa cinta kasih sesama, ridha dan qanaah dengan apa yang diberikan Allah SWT kepadanya serta merasa bahagia". Dengan demikian, kesejahteraan dalam Islam tidak hanya diukur dari terpenuhinya kebutuhan materi saja, tetapi juga terpenuhinya kebutuhan spiritual.

a. Ad-dien (memelihara agama)

b. An-nafs (memelihara jiwa)

c. Al-aql (memelihara akal)

d. An-nasl (memelihara keturunan)

e. Al-maal (memelihara harta)

Menurut Beik dan Arsyianti (2016:602) filosofi kesejahteraan sebagaimana yang dinyatakan dalam Alqur'an yakni Surat Al-Quraisy ayat 1-4 merupakan salah satu konsep yang layak untuk mendapatkan perhatian; (1)Karena kebiasaan orang-orang quraisy (2) (Yaitu) kebiasaan mereka berpergian pada musim dingin dan musim panas (3) Maka hendaklah mereka menyembah tuhan pemilik rumah ini (ka'bah) (4) Yang telah memberi makanan kepada mereka untuk menghilangkan lapar dan mengamankan mereka dari rasa ketakutan. (Kementerian Agama RI, 2014: 602) 
Jika merujuk pada ayat-ayat tersebut, maka konsep kesejahteraan ini memiliki empat indikator utama, yaitu:

a. Sistem nilai Islam, basis dari kesejahteraan ketika nilai ajaran Islam menjadi panglima dalam perekonomian suatu bangsa. Kesejahteraan sejati tidak akan pernah bisa diraih jika kita menentang secara diametral aturan Allah SWT. Penentangan terhadap Allah SWT justru menjadi sumber penyebab hilangnya kesejahteraan dan keberkahan hidup manusia. Indikator pertama untuk kesejahteraan adalah ketergantungan penuh manusia kepada Tuhan pemilik ka'bah,indikator ini merupakan representasi dari pembangunan mental, hal ini menunjukkan bahwa jika seluruh indikator kesejahteraan yang berpijak pada aspek materi telah terpenuhi, hal itu tidak menjamin bahwa pemiliknya akan mengalami kebahagiaan, kita sering mendengar jika ada orang yang memiliki rumah mewah, kendaraan banyak, harta yang melimpah namun hatinya selalu gelisah dan tidak pernah tenang bahkan tidak sedikit yang mengakhiri hidupnya dengan bunuh diri, padahal seluruh kebutuhan materinya telah terpenuhi. Karena itulah ketergantungan manusia kepada tuhannya yang diaplikasikan dalam penghambaan (ibadah) kepada-Nya secara ikhlas merupakan indikator utama kesejahteraan (kebahagiaan yang hakiki) dengan melaksanakan rukun Islam dan rukun iman. Sebagaimana firman Allah SWT dalam surat Thaha ayat 124: Dan barang siapa berpaling dari peringatan-ku, maka sungguh dia akan menjalani kehidupan yang sempit dan kami akan mengumpulkannya pada hari

\section{kiamat dalam keadaan buta.}

(Kementerian Agama RI, 2014: 320)

b. Kekuatan ekonomi

Kesejahteraan tidak mungkin diraih ketika kegiatan ekonomi tidak berjalan sama sekali. Bekerja dengan mendapatkan rezeki yang halal merupakan salah satu cara memperkuat ekonomi suatu masyarakat. Inti dari kegiatan ekonomi terletak pada sektor rill yaitu bagaimana memperkuat industri dan perdagangan. Sektor inilah yang menyerap angkatan kerja dan menjadi inti dari ekonomi syariah. Bahkan sektor keuangan dalam Islam didesain untuk memperkuat kinerja sektor rill, karena seluruh akad dan transaksi keuangan syariah berbasis sektor rill.

c. Pemenuhan kebutuhan dasar dan sistem distribusi

Suatu masyarakat tidak mungkin disebut sejahtera apabila kebutuhan dasar mereka tidak terpenuhi. Indikator ketiga adalah hilangnya rasa lapar (terpenuhinya kebutuhan konsumsi), ayat di atas menyebutkan bahwa "Dialah Allah yang memberi makan untuk menghilangkan rasa lapar", pernyataan tersebut menunjukkan bahwa dalam ekonomi Islam terpenuhinya kebutuhan konsumsi manusia yang merupakan salah satu indikator kesejahteraan hendaknya bersikap secukupnya (hanya untuk menghilangkan rasa lapar) dan tidak boleh berlebih-lebihan apalagi samapai melakukan penimbunan demi mengeruk kekayaan yang maksimal, terlebih lagi jika harus menggunakan cara-cara yang dialarang oleh agama, tentu hal ini tidak sesuai dengan anjuran Allah SWT dalam Surat Quraisy di atas, jika hal itu bisa dipenuhi, maka kita tidak akan menyaksikan adanya korupsi, penipuan, pemerasan, dan bentuk-bentuk kejahatan lainnya. Demikian pula apabila yang bisa memenuhi kebutuhan dasar ini hanya sebagian masyarakat, sementara sebagaian yang lain tidak bisa. Dengan kata lain, sistem distribusi ekonomi memegang peranan penting dalam menentukan kualitas kesejahteraan. Islam 
mengajarkan bahwa sistem distribusi yang baik adalah sistem sistem distribusi yang mampu menjamin rendahnya angka kemiskinan dan kesenangan, serta menjamin bahwa perputaran roda perekonomian bisa dinikmati semua lapisan masyarakat tanpa kecuali.

d. Keamanan dan ketertiban sosial Masyarakat disebut sejahtera apabila friksi dan konflik destruktif antar kelompok dan golongan dalam masyarakat bisa dicegah dan diminalisir. Tidak mungkin kesejahteraan akan dapat diraih melalui rasa takut dan tidak aman. Indikator selanjutnya adalah hilangnya rasa takut, yang merupakan representasi dari terciptanya rasa aman, nyaman dan damai. Jika berbagai macam kriminalitas seperti perampokan, pemerkosaan, pembunuhan, pencurian dan kejahatankejahatan lain banyak terjadi di tengah masyarakat, hal itu menunjukkan bahwa masyarakat tidak mendapatkan ketenangan, kenyamanan dan kedamaian dalam kehidupan, atau dengan kata lain masyarakat belum mendapatkan kesejahteraan.

\section{Tinjauan Penelitian Relevan}

Sebagai bahan rujukan bagi penulis dalam menyusun penelitian ini maka penulis menyampaikan beberapa karya yang mungkin terlibat diantaranya :

a. Penelitian yang dilakukan oleh Abdul Rozak yang berjudul "Peran Bank Sampah Warga Peduli Lingkungan (WPL) dalam Pemberdayaan Perekonomian" hasil dari penelitian adalah peran Bank Sampah Warga Peduli Lingkungan (WPL) dalam meningkatkan perekonomian nasabahnya dapat dikatakan tidak terlalu signifikan, ini berdasarkan hasil dari tabungan sampah dan penjualan barang kerajinan yang jumlahnya masih kecil tiap bulannya. Akan tetapi, walaupun nilai yang didapat nasabah tiap bulannya masih relatif kecil, nasabah masih terbantu dengan adanya Bank Sampah Warga Peduli Lingkungan (WPL) yakni dengan adanya fasilitas pinjaman tanpa bunga, jaminan dan agunan melalui program ROKETS bagi nasabah yang ingin bergabung.

b. Penelitian yang dilakukan oleh Suryani yang berjudul "Peran Bank Sampah dalam Efektifitas Bank Sampah (Studi Kasus Bank Sampah Malang". Hasil dari penelitian ini menemukan bahwa program pengelolaan sampah mandiri melalui bank sampah, telah menjadi salah satu alternatif solusi bagi pemerintah dan masyarakat. Solusi untuk mengurangi peningkatan volume sampah yang semakin tidak terkendali. Sosialisasi pengelolaan sampah mandiri melalui bank sampah, sampai saat ini masih gencar dilakukan oleh pemerintah kota maupun kabupaten. Selain memberikan dampak positif bagi lingkungan, dalam proses pengelolaannya, bank sampah memiliki mekanisme relasi, dan jaringan sosial yang bersifat ekonomis.

c. Penelitian yang dilakukan oleh Ruski dengan judul "Pengaruh Program Bank Sampah Terhadap Tingkat Pendapatan Keluarga Nasabah Bank Sampah Lavender di Desa Milajah Bangkalan". Hasil penelitiannya adalah hasil pengujian hipotesis dengan menggunakan uji $\mathrm{t}$ dapat disimpulkan bahwa adanya pengaruh dari variabel program bank sampah terhadap variabel tingkat pendapatan keluarga nasabah Bank Sampah Lavender (BSL) di Desa Milajah Bangkalan.

\section{METODE}

Metode kuantitatif digunakan dalam penelitian ini untuk menganalisa secara statistik guna melakukan uji penelitian terhadap data-data yang diperoleh dengan menggunakan analisis regresi sederhana. Dimana proses perhitungannya penulis menggunakan alat bantu komputer seperti program software yang dapat digunakan 
untuk mengolah data dalam mengaplikasikan teori-teori statistik diantaranya Program Statistic Package for Sosial Science (SPSS) versi 23.0.

1. Uji Instrumen

Ada dua uji instrumen yang digunakan:

a. Uji Validitas

Uji validitas adalah suatu ukuran yang menunjukkan tingkat kevalidan atau kesahihan suatu instrumen. Suatu instrumen yang valid mempunyai validitas tinggi dan sebaliknya tingkat validitasnya rendah maka instrumen tersebut kurang valid. Sebuah instrumen dikatakan valid apabila mampu mengukur apa yang hendak diukur/diinginkan. (Sanusi, 2014: 76). Metode uji validitas dengan cara mengkorelasikan masingmasing skor item. Skor item adalah penjumlahan dari keseluruhan item. Jika nilai korelasi $r$ hitung lebih besar daripada $r$ tabel maka item kuesioner tersebut dinyatakan valid, sebaliknya jika $r$ hitung lebih kecil dari $r$ tabel atau nilai korelasi negatif maka item tidak valid. $r$ dalam tabel $\alpha=5 \%$ (Priyatno,2016: 53). Dalam metode uji validitas penulis mengunakan SPSS for Windows versi 23,0.

b. Uji Reliabilitas

Reliabilitas instrumen adalah sejauh mana satu pengukuran dapat dipercaya. Jika hasil pengukuran yang dilakukan secara berulang relatif sama maka pengukuran tersebut dianggap memiliki tingkat reliabilitas yang baik atau dapat dipercaya. Reliabilitas suatu alat pengukur menunjukan konsistensi hasil pengukuran sekiranya alat pengukur itu digunakan oleh orang yang sama dalam waktu yang berlainan atau digunakan oleh orang yang berlainan dalam waktu yang bersamaan atau waktu yang berlainan. Secara implisit, reliabilitas ini mengandung objektivitas karena hasil pengukuran tidak terpengaruh oleh siapa pengukurannya. (Sanusi, 2014: 80) Kuesioner dinyatakan reliabel apabila nilai realibilitas hasil perhitungan lebih besar daripada nilai $r$ tabel $\alpha=5 \%$. Dalam metode uji realibilitas penulis mengunakan SPSS for Windows versi 23,0.

2. Uji Hipotesis

Uji hipotesis adalah dengan menguji signifikansi koefisien regresi linier sederhana secara parsial yang terkait dengan pernyataan hipotesis penelitian.

a. Regresi Linear Sederhana

Menurut Sanusi (2014: 131), analisis regresi liner sederhana adalah secara linier antara satu variabel bebas atau independen $(X)$ dengan variabel terikat atau dependen (Y). Analisis ini bertujuan untuk memprediksi nilai variabel dependen apabila nilai variabel independen mengalami kenaikan atau penurunan dan untuk mengetahui arah hubungan antara variabel independen (X) dengan variabel dependen (Y) apakah positif atau negatif.

Menurut Riduwan dan Akdon (2010: 123) rumus regresi linier sederhana adalah sebagai berikut:

$\mathrm{Y}=\mathrm{a}+\mathrm{bX}$

Dimana

$\mathrm{Y}=$ Subjek variabel terikat yang diproyesikan.

$\mathrm{X}=$ Variabel bebas yang mempunyai nilai tertentu yang diprediksikan.

$\mathrm{a}=$ Nilai konstanta $\mathrm{Y}$ jika $\mathrm{X}=0$.

$\mathrm{b}=$ Nilai arah penentu ramalan (prediksi) yang menunjukkan nilai peningkatan $(+)$ atau nilai penurunan $(-)$ variabel $Y$

b. Uji-t (Uji Parsial)

Menurut Sanusi (2014: 146) Uji-t dilakukan untuk mengetahui faktor yang mana yang paling dominan antara variabel bebas dengan variabel terikat dengan uji parsial (Uji-t).

c. Koefisien Korelasi

Koefisien korelasi untuk melihat kuat lemahnya pengaruh antara variabel, 
maka digunakan analisis korelasi. Menurut Riduwan dan Akdon (2010: 124), korelasi adalah istilah statistik yang menyatakan derajat hubungan linear antara dua variabel atau lebih.

d. Koefisien Determinasi $\left(\mathrm{R}^{2}\right)$

Koefisien determinasi adalah angka yang menyatakan atau digunakan untuk mengetahui kontribusi atau sumbangan yang diberikan oleh sebuah variabel (X) terhadap variabel (Y). (Riduwan dan Akdon, 2010: 124)

\section{HASIL}

Penelitian tentang peranan bank sampah terhadap kesejahteraan masyarakat tempatan terdiri dari dua variabel yaitu variabel bebas (peranan bank sampah) dan variabel terikat (kesejahteraan masyarakat tempatan). Analisis data yang digunakan dalam penelitian ini adalah analisis kuantitatif yang digunakan untuk menganalisis secara statistik guna melakukan uji hipotesis terhadap datadata yang diperoleh dengan menggunakan analisis regresi linier sederhana yaitu untuk mengukur pengaruh antara variabel $\mathrm{X}$ terhadap variabel $\mathrm{Y}$ dan proses perhitungan datanya menggunakan program SPSS Versi 23.0. Dari hasil analisis di atas yang pertama penulis melakukan pengujian signifikan atau uji parsial antara peranan bank sampah terhadap kesejahteraan masyarakat tempatan. Dari pengujian tersebut dapat diketahui terdapat pengaruh yang signifikan antara peranan bank sampah terhadap kesejahteraan masyarakat tempatan, ini diketahui dari nilai thitung (13.164) lebih besar dari nilai tabel $(1,684)$. Berarti secara parsial dapat diketahui bahwa variabel $\mathrm{X}$ (peranan bank sampah) berpengaruh terhadap variabel Y (kesejahteraan masyarakat tempatan).
Selanjutnya penulis mencari koefisien korelasi, dimana koesfisien korelasi merupakan bentuk lain yang digunakan untuk menentukan jenis korelasi (hubungan) antara peranan bank sampah terhadap kesejahteraan masyarakat tempatan. Berdasarkan hasil perhitungan, diketahui bahwa besarnya koefisien korelasi (R) peranan bank sampah terhadap kesejahteraan masyarakat tempatan sebesar 90.1\%. Ini menunjukkan hubungan antara peranan bank sampah terhadap kesejahteraan masyarakat tempatan termasuk dalam kategori hubungan sangat kuat. Analisis yang terakhir dilakukan oleh penulis adalah analisis koefisien determinasi, dimana koefisien determinasi $\left(\mathrm{R}^{2}\right)$ merupakan besaran yang menunjukkan seberapa besar kontribusi pengaruh variabel $\mathrm{X}$ (peranan bank sampah) terhadap variabel Y (kesejahteraan masyarakat tempatan). Dari hasil analisis diketahui besarnya nilai kontribusi antara peranan bank sampah terhadap kesejahteraan masyarakat tempatan sebesar $81.2 \%$ sedangkan $18.8 \%$ lainnya dipengaruhi oleh faktor-faktor lain seperti pendidikan kepala keluarga, pekerjaan kepala keluarga, jumlah anggota keluarga, anggota keluarga usia produktif, dan lain sebagainya.

Dilihat dari identitas responden (masyarakat tempatan yang bekerja di bank sampah) mengenai pendidikan terakhirnya pada umumnya adalah tingkat SMA/MA/sederajat. Sehingga responden tidak memiliki keterampilan khusus yang dapat digunakan untuk mencari pekerjaan. Dengan adanya bank sampah ini, responden dapat dilatih dan diberdayakan sehingga mereka bisa mendapatkan pekerjaan yang menghasilkan sumber penghasilan baru bagi keluarganya. Jika dilihat dari jenis pekerjaan responden, pada umumnya responden bekerja sebagai pengrajin. Pengrajin memiliki rentang upah yakni $<$ Rp.1.000.000/bulannya. Namun dari hasil penelitian mereka menyatakan upah yang didapat < Rp. 500.000/ bulannya. Penghasilan mereka tiap bulannya tidak dapat ditetapkan, karena pengurus bank sampah menilai pengrajin dari seberapa 
$\begin{array}{lcc}\text { produktifnya } & \text { mereka } & \text { dalam } \\ \text { menghasilkan } & \text { kerajinan } & \text { olahan }\end{array}$ sampah.

Dari hasil wawancara yang peneliti lakukan, responden menganggap bahwa upah yang mereka terima memang dirasakan masih rendah, sehingga mereka tidak memiliki motivasi yang tinggi dalam memproduksi kerajinan-kerajinan tersebut. Sedangkan petugas sampah memiliki rentang upah antara Rp. 1.000.000 - Rp. 1.500.000. rentang gaji yang didapat oleh petugas sampah ini juga dilihat dari seberapa besar produktivitas karyawan dalam mengambil, membersihkan dan memilah sampah. Namun, rentang gaji yang diberikan oleh pengurus bank sampah ini pun masih dirasakan rendah karena belum mencapai standar gaji UMK perbulannya, sehingga dari segi penghasilan yang mereka dapatkan karyawan bank sampah belum masuk ke dalam kategori karyawan yang sejahtera. Responden pada umumnya telah bekerja lebih dari tiga tahun di bank sampah ini, responden menganggap bahwa sejak bank sampah diresmikan tahun 2012, tidak terjadi peningkatan upah yang signifikan padahal mereka merasakan pengeluaran dan kebutuhan mereka tiap tahunnya semakin meningkat.

$$
\text { Pada pernyataan angket }
$$

kesejahteraan material, responden pada umumnya menjawab setuju karena sumber penghasilan responden bukan merupakan sumber utama penghasilan keluarga, namun berbentuk penghasilan tambahan dikarenakan responden menganggap bahwa kerja di bank sampah hanya sebagai kerja sampingan. Responden menyatakan setuju bahwa mereka telah memiliki rumah layak huni baik yang berupa rumah pribadi maupun rumah sewa, makan dan minum yang cukup, pakaian yang layak, serta kesehatan yang baik. Jadi dapat disimpulkan bahwa bank sampah belum memberikan kesejahteraan material yang maksimal bagi para karyawan. Kesejahteraan dalam perspektif ekonomi Islam adalah kesejahteraan yang menyeluruh. Konsep kesejahteraan dalam ekonomi Islam tidak hanya dilihat dari kesejahteraan materialnya saja. Namun juga mencakup kesejahteraan moral, kesejahteraan spiritual dan kesejahteraan sosial. Jika dilihat dari sisi kesejahteraan spiritual, karyawan bank sampah telah memenuhi kesejahteraan spiritual.

Berdasarkan angket yang telah peneliti berikan kepada karyawan jawaban yang paling tertinggi adalah mereka telah memiliki keluarga yang sakinah mawaddah dan warahmah. Hal ini didukung dengan jawaban pernyataan angket lainnya bahwa karyawan telah melaksanakan aktivitas ibadahnya dengan rutin, karyawan telah merasakan keberkahan atas rezeki yang mereka dapatkan serta karyawan telah memiliki sikap ridha dan qanaah atas apa yang telah diberikan Allah SWT. Sedangkan kesejahteraan moral karyawan bank sampah pun telah terpenuhi karena karyawan menganggap bahwa dirinya dapat menghargai karyawan lainnya apabila terdapat perbedaan pendapat, karyawan memiliki sikap santun terhadap pimpinan dan karyawan lainnya dan karyawan memiliki hubungan yang baik antara sesama karyawan, pimpinan dan pengurus bank sampah. Jika dilihat dari kesejahteraan sosial pun telah terpenuhi karena karyawan merasa dihargai dengan perubahan sosial secara perlahan setelah bekerja di bank sampah, karyawan merasa telah memenuhi hak dan kewajibannya dalam melaksanakan pekerjaannya. Namun pada pernyataan angket kesejahteraan sosial, responden menjawab mereka belum mampu membayar zakat hal ini dikarenakan mereka menganggap bahwa pengahasilan mereka saat ini hanya cukup untuk memenuhi kebutuhan sehari-hari mereka, sehingga tidak memiliki uang lebih untuk mengeluarkan zakat, namun mereka berusaha untuk selalu berinfak atau bersedekah setiap hari, pekan atau bulannya. 


\section{SIMPULAN}

Berdasarkan dari hasil pembahasan yang telah diuraikan sebelumnya maka penulis dapat menyusun beberapa kesimpulan sebagai berikut:

1. Dari hasil uji parsial diketahui bahwa terdapat pengaruh yang signifikan antara peranan bank sampah terhadap kesejahteraan masyarakat tempatan.

2. Koefisien korelasi menyatakan adanya hubungan yang sangat erat antara peranan bank sampah terhadap kesejahteraan masyarakat tempatan.

3. Sedangkan koefisien determinasi menunjukkan terdapat kontribusi yang sangat besar dari peranan bank sampah kepada kesejahteraan masyarakat tempatan.

4. Kesejahteraan karyawan bank sampah yang merupakan masyarakat tempatan belum dapat dikatakan sesuai dengan perspektif ekonomi syariah karena kesejahteraan material karyawan belum terpenuhi, sedangkan kesejahteraan spiritual, kesejahteraan moral dan kesejahteraan sosial karyawan telah terpenuhi.

\section{DAFTAR RUJUKAN}

Beik, Irfan Syauqi dan Laily Dwi Arsyianti, 2016, Ekonomi Pembangunan Syariah, Rajawali Pers, Jakarta.

Kementerian Agama RI. Al-Qur'an AlKarim dan Terjemahannya, 2014, Sygma, Semarang.

Munawir, 2015, Bank Sampah Upaya Pemberdayaan Masyarakat dan Penanganan Lingkungan, Jurnal Bisnis dan Manajemen, Vol. 1, p.31-37.

Pusat Pengkajian dan Pengembangan Ekonomi Islam (P3EI) UII Yogyakarta, 2008, Ekonomi
Islam, PT. Rajagrafindo Persada, Jakarta.

Pusat Bahasa, 2008, Kamus Besar Bahasa Indonesia Edisi Keempat, Gramedia, Jakarta.

Priyatno, Duwi, 2016, SPSS Handbook Analisis Data, Olah Data dan Penyelesaian Kasus-Kasus Statistik, Mediakom, Yogyakarta.

Riduwan dan Akdon, 2010, Rumus dan Data Dalam Analisis Statistika, Alfabeta, Bandung.

Sanusi, Anwar, 2014, Metodologi Penelitian Bisnis, Salemba Empat, Jakarta.

Soekonto, Soerjono, 2015, Sosiologi Suatu Pengantar, Rajawali Pers, Jakarta.

Suyomukti, Nurani, 2016, Pengantar Sosiologi: Dasar Analisis, Teori dan Pendekatan Menuju Analisis MasalahMasalah Sosial, Perubahan Sosial dan Kajian-Kajian Strategis, Ar-Ruzz Media, Jogjakarta.

Wirawan, 2015, Manajemen Sumber Daya Manusia Indonesia, PT Raja Grafindo Persada, Jakarta. 